KS. WIESEAW PRZYGODA

\title{
WYZWANIA DUSZPASTERSKIE WOBEC OSÓB W PODESZŁYM WIEKU ${ }^{1}$
}

Wezwaniem do poszukiwania nowych form pracy duszpasterskiej wśród ludzi starych są inicjatywy podejmowane przez różne organizacje międzynarodowe. ONZ w 1982 roku zorganizowała w Wiedniu pierwszą, a w 2002 roku w Madrycie drugą Światową Konferencję na Temat Osób Starych. Również z inicjatywy ONZ dzień 1 października został w 1990 roku ogłoszony Międzynarodowym Dniem Osób Starszych, a 1999 rok był obchodzony jako Międzynarodowy Rok Ludzi Starych, co stało się sposobnością do zwrócenia uwagi ludzkości na potrzebę budowania społeczeństwa dla ludzi w każdym wieku przez usuwanie barier dyskryminacji i ubóstwa, które spychają ludzi starszych na margines życia. Papieska

1 Artykuł ukazał się w czasopiśmie „Polonia Sacra” 19 (2015) nr 1 (38), s. 49-69, http://dx.doi.org/10.15633/ps.729. 
Rada do spraw Duszpasterstwa Służby Zdrowia zorganizowała w dniach 28-31 X 1998 roku w Watykanie konferencję na temat: Kościót a ludzie starzy. Papieska Rada do spraw świeckich ogłosiła w 1998 roku dokument pt. Godność i posłannictwo ludzi starszych $w$ Kościele $i w$ świecie, a św. Jan Paweł II wydał specjalny List do ludzi w podeszłym wieku (1 X 1999 roku). W Polsce w 2007 roku odbył się III Kongres Ruchów i Stowarzyszeń Katolickich, który przebiegał pod hasłem: Ludzie starsi - nadzieją Kościoła i społeczeństwa. Wspomniane inicjatywy ukazują, jak ważną rolę ludzie w podeszłym wieku mają do odegrania nie tylko w społeczeństwie, lecz także we wspólnocie Kościoła.

Specyfika wieku senioralnego, coraz lepiej rozpoznawana przez gerontologię, psychologię, socjologię i nauki pokrewne, stanowi wyzwanie dla współczesnego Kościoła, który pragnie wszystkie grupy swoich wiernych otaczać adekwatną do ich potrzeb troską duszpasterską. W tym opracowaniu zostaną przedstawione najpierw specyficzne potrzeby religijne ludzi w podeszłym wieku, następnie cele i formy duszpasterstwa seniorów, by w końcowej części skoncentrować się na tym, co z punktu widzenia samych zainteresowanych wydaje się bezcenne, a mianowicie na aktywizacji apostolskiej ludzi starszych. 


\section{1. \\ Specyfika potrzeb religijnych ludzi starszych}

Adresatami pastoralnej troski Kościoła są trzy grupy ludzi starych, których Światowa Organizacja Zdrowia (WHO) dzieli na ludzi: w wieku podeszłym (60-75 lat), starczym (76-90 lat) i sędziwym (powyżej 90 lat) $)^{2}$. Ze względu na kryterium redukcji sił fizycznych, psychicznych i umysłowych rozróżnia się: ludzi starych o zredukowanych siłach i umiejętnościach fizycznych, psychicznych i umysłowych; ludzi starych sprawnych fizycznie, u których nastąpiła redukcja $\mathrm{w}$ obszarze psychiczno-umysłowym; ludzi starych o dużych możliwościach umysłowych i dobrej kondycji psychicznej i o bardzo zredukowanych siłach fizycznych. W duszpasterstwie seniorów należy uwzględniać te różnice i brać je pod uwagę przy doborze metod posługi duszpasterskiej ${ }^{3}$. Należy ponadto pamiętać, iż ludzie starsi mają swoje przekonania i zasady życia, odznaczają się dużym zaufaniem do Boga i instytucji Kościoła, a ich poglądy charakteryzuje spójność przekonań i działań, jednolity obraz

2 W niniejszym opracowaniu pojęcia: „ludzie w podeszłym wieku”, „ludzie starzy”, „ludzie starsi” i „seniorzy” będą stosowane zamiennie na określenie wszystkich ludzi starych bez rozróżniania ich szczegółowych podkategorii.

3 Zob. K. Baumgartner, Alte Menschen, [w:] Handbuch praktische Theologie, Hg. H. Haslinger, Mainz 2000, t. 2, s. 61-71. 
świata, w którym sfera religii i doczesności nie są wyraźnie rozdzielone.

Współcześnie pojawił się nowy problem rosnącej liczby ludzi starych w krajach wysoko rozwiniętych, co spowodowane jest postępem medycyny oraz polepszeniem warunków pracy i ogólnym wzrostem dobrobytu. Zwłaszcza w społeczeństwach zlaicyzowanych ludzie starzy są postrzegani jako przeszkoda i permanentnie marginalizowani ${ }^{4}$. Najtragiczniejszym przejawem marginalizacji ludzi starszych jest eutanazja proponowana $\mathrm{z}$ coraz większą natarczywością w społeczeństwach o nastawieniu konsumpcyjnym. Zadaniem Kościoła jest dzisiaj nie tylko obrona życia od poczęcia do naturalnej śmierci ${ }^{5}$, lecz także uwrażliwianie na wartość życia ${ }^{6}$. Kościół szanuje każde życie ludzkie, obejmując swą troską duszpasterską ludzi starych, w tym także przewlekle chorych. Pod koniec swego życia w Orędziu na Wielki Post 2005 roku św. Jan Paweł II podkreślił, iż zachodzi „konieczność zwrócenia szczególniejszej uwagi

4 Zob. M. Kluz, Starość i jej problemy we współczesnej cywilizacji, [w:] Przestrzenie pracy socjalnej, red. J. Stala, Tarnów 2010, s. 89-106.

5 Jan Paweł II, Novo millennio ineunte. List apostolski na zakończenie Wielkiego Jubileuszu Roku 2000, 6 stycznia 2001 [dalej: NMI], 51.

6 Jan Paweł II, List Do moich Braci i Sióstr - ludzi w podeszłym wieku, 1 października 1999 [dalej: LdS], 9. 
na świat tzw. «trzeciego wieku», aby pomóc tym, którzy go tworzą, wykorzystywać w sposób pełny swe możliwości dla dobra całego społeczeństwa. [...] Życie człowieka to cenny dar: należy je kochać i bronić go w każdej fazie"?.

Starość pozwala na różne sposoby doświadczyć kondycji bytu stworzonego przez Boga. W sposób pozytywny kondycja ta ujawnia się jako dojrzałość, wypełnienie i mądrość, a w sposób negatywny wyraża się doświadczeniem skończoności, zależnością od pomocy innych ludzi. Wśród problemów ludzi podeszłego wieku eksperci wymieniają na pierwszym miejscu samotność, następnie chorobę i inwalidztwo, życie w ubóstwie, brak poczucia bezpieczeństwa, poczucie nieprzydatności, w końcu stopniową eliminację z życia oraz nietolerancję wynikającą z tzw. kultu zdrowia i młodości ${ }^{8}$. Dlatego ludzie starsi powinni otrzymać od młodszych grup wiekowych społeczeństwa i Kościoła należny szacunek, towarzyszenie w cierpieniu oraz niezbędną opiekę.

W nowoczesnym społeczeństwie zmieniła się struktura rodziny, która $\mathrm{z}$ modelu wielopokoleniowego $\mathrm{w}$ społeczeństwie agrarnym przekształciła się

7 Jan Paweł II, Bo tu jest twoje życie i dtugie trwanie twego pobytu na ziemi. Orędzie na Wielki Post 2005, 8 września 2004, 3.

8 B. Krzyżagórska, Ludzie starsi - nadzieja Kościoła i społeczeństwa, www.orrk.pl/index.php/kongresy-tematyczne/apostolstwo-ludzi-starszych (7.05.2014). 
w rodzinę dwupokoleniową, często osamotnioną, niestabilną, a nawet rozbitą, do czego przyczyniają się migracje polityczne i zarobkowe. W takich uwarunkowaniach ludzie starzy przeżywają wiele niedogodności, cierpią biedę i samotność, brakuje im aktywności, a wraz z postępem lat, osłabieniem sił i nasileniem się chorób coraz mocniej odczuwają swą słabość i ciężar życia. Dotychczas uważano, że wystarczy zapewnić ludziom starszym odpowiednie warunki materialne i niezbędną opiekę. Tymczasem seniorzy zgłaszają potrzeby wyższego rzędu, takie jak: potrzeba utrzymywania stosunków rodzinnych, potrzeba wypełnienia wolnego czasu, potrzeba pracy społecznej, potrzeba kształcenia intelektualnego i autoekspresji, potrzeba aktywności religijnej, potrzeba pomocy w chorobie i cierpieniu itp. ${ }^{9}$.

Według ogłoszonego 1 X 1998 roku przez Papieską Radę do spraw Świeckich dokumentu pt. Godność i posłannictwo ludzi starszych w Kościele i w świecie starość nie musi być przeżywana w stanie biernej rezygnacji, przechodzącej niekiedy w stan sprzeciwu czy beznadziejnej, rozpaczliwej ucieczki ${ }^{10}$. Obecność

9 Tamże; zob. M. Żaba, Ludzie starsi w Kościele, „Caritas” nr 4 (2012), s. 10-11.

10 Pontificium Consilium pro Laicis, La dignità dellanziano e la sua missione nella Chiesa e nel mondo, 1 października 1998, rozdz. I, http://vatican.va/roman_curia/pontifical_concils/laity/laity_it (7.05.2014). Streszczenie tego dokumentu w języ- 
coraz większej liczby osób starych we współczesnym świecie należy postrzegać w kategoriach duchowego bogactwa i daru dla ludzkości. To „bogactwo” okresu starości nosi pewne cechy charyzmatyczne, a zwłaszcza darmowość jako przeciwwagę dla nastawienia utylitarnego panującego $\mathrm{w}$ dzisiejszym świecie, pamięć i doświadczenie, wzajemną zależność oraz bardziej całościową wizję życia. Starość częściej stawia przed ludźmi pytania o sens i godność życia, o powołanie i przeznaczenie człowieka. Ludzie starsi doceniają wartość modlitwy, religijności, moralności i życia duchowego, a także ukazują wyższość kategorii "być" nad „mieć" i „działać”"1.

Starość nie jest chorobą, lecz naturalnym okresem życia. Toteż w okresie starości chrześcijanin w miarę swoich możliwości powinien w dalszym ciągu realizować własne zadania życiowe ${ }^{12}$. Z mądrości i doświadczenia ludzi starszych powinno korzystać w pierwszej kolejności ich środowisko rodzinne, a następnie szersze środowisko społeczne, do którego oni należą.

ku polskim w: E. Weron, O godna starość. Refleksje człowieka wierzącego, Poznań 2000, s. 53-61.

11 Jan Paweł II, Cenna rola osób starszych w Kościele. Audiencja generalna, 7 września 1994, „L'Osservatore Romano” wyd. pol. 15 (1994) 11, s. 39.

12 Zob. J. Dziedzic, Das Alter - ein Problem oder eine Chance? Versuch einer multiperspektivischen pastoralen Refleksion, „Analecta Cracoviensia” 43 (2011), s. 25-41. 
Ludzie w podeszłym wieku dzięki swej dojrzałości i doświadczeniu mogą udzielać cennych rad i życiowych wskazań przede wszystkim młodszym członkom swoich rodzin. W duszpasterstwie osób starszych należy zatem z jednej strony pamiętać o ograniczeniach wynikających $\mathrm{z}$ ich wieku i stanu zdrowia, a $\mathrm{z}$ drugiej strony należy umożliwić wspólnocie Kościoła korzystanie z tych wartości, jakie mogą do niej wnieść tylko ludzie starsi.

\section{2. \\ Cele, podmiot i formy duszpasterstwa seniorów}

Kościół od zarania swych dziejów, nawiązując do utrwalonego w Starym Testamencie szacunku dla ludzi starych, obejmował ich swoją troską pasterską i stara się to czynić również współcześnie. Duszpasterstwo seniorów (ludzi starszych) to „zorganizowana działalność Kościoła zmierzająca do uświęcenia i zbawienia osób w podeszłym wieku przez głoszenie im słowa Bożego, sprawowanie sakramentów, posługę charytatywną oraz działalność integracyjną i społeczną"13. Należy na wstępie podkreślić, iż ludzie starsi są

13 W. Przygoda, Starych duszpasterstwo, [w:] Encyklopedia katolicka, red. E. Gigilewicz i in., t. 18, Lublin 2013, kol. 868; por. 
nie tyle przedmiotem, co raczej podmiotem działalności zbawczej Kościoła, z czego chyba oni sami rzadko zdają sobie sprawę. Toteż ludziom starszym potrzebna jest pomoc, by nie pojmowali starości jako biernego oczekiwania na śmierć, ale mogli również w tym okresie życia realizować swoje powołanie w Kościele i świecie.

Duszpasterstwo pomaga osobom starszym kontynuoować rozwój kondycji fizycznej, intelektualnej i duchowej. Czas starości nie może być bowiem pojmowany jako bierne oczekiwanie na śmierć. Chrześcijańska wiara nakazuje przeżywać lata starości w postawie zaufania Bogu i twórczo je spożytkować, choćby „do pogłębienia życia duchowego przez usilniejszą modlitwę i gorliwą służbę braciom w miłości” (LdS 16). Dlatego cenne są wszelkie inicjatywy społeczne i kościelne, które pomagają ludziom starszym dbać o kondycję fizyczną i intelektualną, ale także umożliwiają im rozwijanie relacji z innymi, oddawanie swego czasu, umiejętności, doświadczenia oraz rozmaitych posług.

Do celów duszpasterstwa seniorów należą:

- nauka modlitwy i pogłębianie życia duchowego;

- przygotowanie do życia sakramentalnego;

J. Ostrowski, W. Przygoda, Seniorów duszpasterstwo, [w:] Leksykon teologii pastoralnej, red. R. Kamiński, W. Przygoda, M. Fiałkowski, Lublin 2006, s. 789. 
- pogłębianie świadomości religijnej;

- umacnianie wiary w Boga w kontekście przemijalności życia;

- pomoc w zrozumieniu bieżących spraw w perspektywie całego życia;

- kształtowanie poczucia odpowiedzialności za innych i szacunku dla życia;

- kształtowanie postawy ofiarności w posłudze bliźniemu;

- troska o relacje międzyludzkie oparte na wierze i Ewangelii.

Według nauczania Kościoła obowiązek troski o ludzi starszych spada w pierwszej kolejności na rodzinę. Obecność ludzi w podeszłym wieku w kręgu rodzinnym ukazuje ciągłość pokoleń oraz wzajemne wspomaganie w wypełnianiu różnych zadań i zdobywaniu świętości (KK 11). Spychanie osób starych na margines życia jest nie tylko źródłem ich cierpienia, lecz także jedną z przyczyn duchowego zubożenia współczesnej rodziny. Czwarte przykazanie Dekalogu zobowiązuje dzieci do okazywania czci rodzicom. Szczególnym sprawdzianem realizacji tego przykazania jest okres starości rodziców. Nakazem sprawiedliwości jest wdzięczność dzieci dla rodziców potwierdzona w okresie ich dorosłego życia czynami dobra, posługi i miłości. Szacunek dla seniorów w rodzinie powinien przejawiać się $\mathrm{w}$ akceptowaniu ich obecności, udzielaniu im pomocy i docenianiu ich zalet 
(LdS 12). Dokument II Polskiego Synodu Plenarnego podkreśla, że starzy rodzice mogą przyczynić się do budowania więzi rodzinnych przez przykład zachowania hierarchii wartości, troski o przekaz wiary, pokój wewnętrzny i zgodę w rodzinie ${ }^{14}$. Komunia osób $\mathrm{w}$ rodzinie wielopokoleniowej oparta na miłości jest dla wszystkich szkołą bogatszego człowieczeństwa.

Istotną rolę w duszpasterstwie osób starszych spełniają wspólnoty parafialne. Seniorzy aktywnie uczestniczący przez wiele lat w życiu parafii nie powinni być pozbawieni tego uczestnictwa na starość. W większości parafii w Polsce ludzie starzy mają zagwarantowaną duszpasterską opiekę duchową. Do nich także jest zaadresowana szeroka oferta nabożeństw nadobowiązkowych. W obliczu postępującego procesu starzenia się społeczeństwa polskiego należy jednak poszukiwać nowych form obecności i aktywności w życiu parafialnym ludzi w podeszłym wieku. W ramach organizacyjnych parafii ważną rolę w duszpasterstwie seniorów odgrywaja również ruchy i stowarzyszenia chrześcijańskie, które umożliwiają seniorom osobisty rozwój życia duchowego, poznawanie nowych form pobożności chrześcijańskiej oraz różne formy zaangażowania apostolskiego.

14 II Polski Synod Plenarny (1991-1999), Powołanie do życia w małżeństwie i rodzinie, 13, Poznań 2001, s. 34. 
Do podstawowych form duszpasterstwa seniorów należą głoszenie słowa Bożego, liturgia i diakonia. W odniesieniu do osób starszych należy jednak starać się wypracować odpowiedni język przekazu ewangelicznego, który odpowiadałby ich mentalności i problemom. Istotnym elementem ewangelizacji seniorów jest ich czynne włączenie w katechezy, spotkania dyskusyjne i kręgi modlitewne. Należy dowartościować doświadczenie ludzi w podeszłym wieku, zdobyte wraz z latami życia, gdyż może ono stać się źródłem wskazań dla pozostałych grup parafian, utrwalając obyczaje, tradycje i przekonania wspólnoty parafialnej. W duszpasterstwie seniorów chodzi także o ponowne odkrywanie solidarności międzypokoleniowej.

II Polski Synod Plenarny zachęca duszpasterzy do tworzenia klubów seniora (trzeciego wieku) lub wspólnot ludzi starszych. Podczas badań ankietowych przeprowadzonych w 2010 roku przez Wiesława Przygodę na ogólnopolskiej próbie 722 wolontariuszy z parafialnych zespołów Caritas zapytano ich, czy istnieje na terenie parafii ich zamieszkania klub seniora, weterana lub emeryta. Uzyskane wyniki wskazują, że według $37,1 \%$ respondentów w parafii ich zamieszkania istnieje klub seniora, weterana lub emeryta. 46,8\% respondentów stwierdziło, że taki klub nie istnieje, $14,4 \%$ nie wiedziało, czy taki klub istnieje, a $1,7 \%$ nie udzieliło na to pytanie żadnej 
odpowiedzi. Istnienie klubu seniora, weterana lub emeryta potwierdzili częściej respondenci zamieszkali w dużym $(44,3 \%)$ lub małym mieście $(42,5 \%)$ niż respondenci zamieszkali na wsi $(25,0 \%)^{15}$. A zatem kluby dla osób w podeszłym wieku powstają częściej w środowisku miejskim niż w środowisku wiejskim i wszystko wskazuje na to, że w przyszłości będzie ich przybywać. Stanowią one okoliczność sprzyjającą rozwijaniu różnych form aktywizacji osób w podeszłym wieku. Wolontariusze z parafialnych zespołów Caritas w ścisłej współpracy z zarządami lub prezesami wspomnianych klubów mogą aranżować bale charytatywne, spotkania rekreacyjno-towarzyskie, spotkania świąteczne, a także pielgrzymki, wycieczki i wyjazdy turystyczne. We współpracy z proboszczem miejscowej parafii wolontariusze mogą zapraszać ludzi starszych uczestniczących w działalności klubu do kościoła parafialnego na Msze św., nabożeństwa i czuwania modlitewne dla osób starszych. Ponadto można zaproponować członkom klubu seniora katechezy, prelekcje, spotkania z ciekawymi ludźmi lub przygotowane przez młodzież wieczornice z poezją religijną.

15 W. Przygoda, Apostolski wymiar wolontariatu charytatywnego $w$ Polsce. Studium teologicznopastoralne na podstawie badań wolontariuszy z parafialnych zespołów Caritas, Lublin 2012, s. 236-237. 
Parafialne kluby seniora nie są jedynym sposobem przezwyciężania samotności i poczucia niskiej wartości ludzi starszych w parafii. Najprostszą alternatywą w przypadku braku w pobliżu klubu seniora wydają się być spotkania seniorów w domu parafialnym. We wspomnianych wyżej badaniach zapytano respondentów, jak często odbywają się spotkania ludzi starszych $\mathrm{w}$ domu parafialnym. $\mathrm{Na}$ to pytanie odpowiedziało zaledwie $57,1 \%$ ankietowanych wolontariuszy. Według 4,6\% respondentów spotkania seniorów odbywają się z regularnością przynajmniej raz $\mathrm{w}$ tygodniu. $1,0 \%$ badanych wolontariuszy wskazało, że takie spotkania odbywają się dwa razy w miesiącu, a 6,1\% że raz w miesiącu. Według 16,3\% ankietowanych osób takie spotkania odbywają się kilka razy w roku, a według 13,9\% tylko raz w roku. 13,9\% respondentów stwierdziło, że takie spotkania nie są wcale w parafii organizowane, a $42,9 \%$ nie udzieliło na to pytanie żadnej odpowiedzi ${ }^{16}$.

Wydaje się, że do regularnych spotkań seniorów w domu parafialnym można zaliczyć tylko te, które odbywają się przynajmniej raz w miesiącu. Takie spotkania potwierdziło w sumie zaledwie $11,7 \%$ respondentów, zdecydowanie częściej wywodzących

16 W. Przygoda, Apostolski wymiar wolontariatu..., dz. cyt., s. 237. 
się z miast dużych lub małych niż ze wsi. Spotkania odbywające się rzadziej niż raz w miesiącu należy zakwalifikować jako spotkania okazjonalne. $\mathrm{Z}$ analizy szczegółowych danych wynika, że jeśli już dochodzi do spotkań seniorów w domu parafialnym, to są to najczęściej bale, spotkania rekreacyjno-towarzyskie lub spotkania świąteczne. Rzadziej podczas tych spotkaniach odbywają się katechezy dla dorosłych, prelekcje, odczyty popularnonaukowe, spotkania z ciekawymi ludźmi lub wieczornice artystyczne. Powodem spotkań ludzi starszych są także sprawy organizacyjne związane z pielgrzymkami lub wycieczkami. Uzyskane w badaniach informacje pokazują, jak wiele jest jeszcze do zrobienia i do rozwinięcia w polskich parafiach w zakresie troski o ludzi starszych. Animatorami tego rozwoju powinni być niewątpliwie proboszczowie, natomiast ich głównym wsparciem w tej działalności powinni być wolontariusze z parafialnych zespołów Caritas ${ }^{17}$.

W duszpasterstwie ludzi w podeszłym wieku należy ich zachęcać, by nie lękali się korzystać $\mathrm{z}$ sakramentu namaszczenia chorych i nie odkładali go na czas ostatniej choroby, kiedy Kościół proponuje wiatyk jako Komunię na ostatnią drogę (KKK 1524). Według nauczania Kościoła sakrament chorych nie tylko

17 W. Przygoda, Apostolski wymiar wolontariatu..., dz. cyt., s. 238. 
skutkuje odpuszczeniem grzechów, ale także sprzyja powrotowi do zdrowia i pomaga choremu w odzyskaniu wewnętrznego pokoju (zob. Jk 5, 14-15; KKK 1520). Warta upowszechnienia jest stosowana już w wielu parafiach praktyka wspólnotowego udzielania sakramentu chorych przy okazji misji i rekolekcji parafialnych.

W duszpasterstwie parafialnym należy organizować okolicznościowe nabożeństwa dla seniorów, połączone ze spotkaniami dla nich w pomieszczeniach parafialnych. Okazją do takich spotkań może być Dzień Babci i Dziadka, dzień chorych, Wigilia, opłatek, Wielkanoc, odpust parafialny itp. Starszych ludzi należy angażować $\mathrm{w}$ różne przedsięwzięcia parafialne. Mogą oni wykonywać niektóre prace porządkowe, biurowe, poprowadzić sklepik parafialny itp. Ludzie utalentowani mogą wykonywać różne przedmioty rękodzielnicze przeznaczone na loterię fantową, a kobiety piec ciasta na kiermasz świąteczny. Seniorom należy ponadto proponować uczestnictwo w parafialnych grupach apostolskich, kołach żywego różańca, kręgu biblijnym, Uniwersytetach Trzeciego Wieku, a także w parafialnym zespole Caritas. Im więcej grup religijnych funkcjonuje w parafii, tym większe jest poczucie wspólnoty ogółu parafian, a seniorom łatwiej odnaleźć własną grupę spełniającą oczekiwania i specyficzne potrzeby religijne. Zaangażowanie apostolskie z kolei 
pozwala seniorom zachować poczucie własnej wartości i przyczynia się do ich integracji ze wspólnotą parafialną.

Starość bywa niestety dosyć często naznaczona samotnością i chorobami. Podstawą opieki charytatywno-socjalnej nad ludźmi starszymi jest zapewnienie im stałości środowiska, przy czym najlepsze z ich punktu widzenia jest środowisko domu rodzinnego. Opieka nad ludźmi starszymi jest szczególnie trudna i wymaga odpowiednich predyspozycji i mocnego zaangażowania opiekuna. Głównym zadaniem opiekuna jest zapewnienie człowiekowi staremu spokoju i bezpieczeństwa. Istotnym elementem terapii chorych i samotnych staruszków jest podtrzymywanie ich kontaktu ze światem i pobudzanie własnej aktywności. Należy zwrócić uwagę na to, aby proponowana seniorom aktywność była adekwatna do ich wieku, możliwości intelektualnych i fizycznych oraz osobistych zainteresowań. Opieka nad człowiekiem w wieku sędziwym może okazać się ciężką pracą, której rodzina bez pomocy $\mathrm{z}$ zewnątrz często nie jest $\mathrm{w}$ stanie podołać. Dlatego $\mathrm{w}$ środowisku lokalnym parafii, gminy, osiedla należy tworzyć grupy wsparcia, wolontariat ukierunkowany na pomoc ludziom starszym, a także środowiskowe domy pobytu dziennego dla seniorów.

Znaczącą pomoc rodzinie $\mathrm{w}$ opiece nad ludźmi starymi mogą świadczyć pielęgniarki środowiskowe, 
a zwłaszcza stacje opieki Caritas. Kompleksowy program opieki pielęgnacyjnej i rehabilitacyjnej nad osobami chorymi, niepełnosprawnymi i starymi jest realizowany przez organizację Caritas przy współudziale instytucji państwowych i samorządowych ${ }^{18}$. Stacje opieki Caritas oferują opiekę pielęgniarską oraz proste zabiegi rehabilitacyjne ludziom chorym, niepełnosprawnym i starym w ich domach rodzinnych Do budynku stacji opieki Caritas są oni przywożeni tylko na skomplikowane zabiegi. Personel stacji opieki Caritas nie tylko odciąża członków rodziny w opiece nad przewlekle chorymi, lecz spełnia też funkcję edukacyjną w zakresie pielęgnacji chorych, rehabilitacji, higieny i sposobów odżywiania. Pielęgniarki są wyposażone w samochody i telefony komórkowe, by mogły skutecznie i na czas docierać do potrzebujących w miejscach ich zamieszkania. W siedzibach stacji opieki Caritas znajdują się

18 Projekt stacji opieki Caritas zainaugurowany został w 1992 roku w Dobrzeniu Wielkim z inicjatywy Caritas Diecezji Opolskiej. Dynamiczny rozwój sieci stacji opieki Caritas nastąpił w Polsce po podpisaniu przez Caritas Polska umowy z Caritas w Niemczech, na której mocy niemiecka Caritas zobowiązała się wesprzeć finansowo ten projekt. W latach 1994-1997 Caritas w Niemczech zaopatrzył kilkadziesiąt stacji opieki Caritas w samochody oraz sprzęt medyczny i rehabilitacyjny. Zob. W. Przygoda, Stacje opieki Caritas, [w:] Leksykon teologii pastoralnej, dz. cyt., s. 814-815. 
bardziej skomplikowane urządzenia rehabilitacyjne oraz wypożyczalnie sprzętu dla chorych i niepełnosprawnych, w których można bezpłatnie wypożyczyć wózki inwalidzkie, chodziki i balkoniki, kule ortopedyczne, materace przeciwodleżynowe, łóżka szpitalne i rehabilitacyjne, a także inny sprzęt niezbędny do życia ludziom starszym.

Ponieważ przybywa w Polsce ludzi starych samotnych, niekiedy wymagających intensywnej opieki ze względu na choroby lub zaawansowane procesy geriatryczne, należy rozwijać sieć domów opieki społecznej. Ważne jest, by nie tylko wzrastała liczba takich domów, ale również podnosił się poziom oferowanej w nich opieki socjalnej. Dobrą formą troski o ludzi starych są również świetlice i domy dziennego pobytu dla seniorów, które umożliwiają im spotkanie w szerszym gronie rówieśników i godziwe przeżycie kilku godzin w ciągu dnia. Dla najbiedniejszych seniorów należy organizować tygodniowe lub dłuższe charytatywne turnusy wypoczynkowe. Lista pomysłów na ciekawy sposób zagospodarowania czasu i charyzmatów ludzi w podeszłym wieku nie została tu wyczerpana. Jest ona wciąż otwarta i niewątpliwie będą się pojawiać, czy to w naszym kraju, czy za granicą, nowe pomysły i sposoby troski o seniorów, które należy dostrzegać i jak najszerzej upowszechniać. 
3.

Kierunki aktywizacji apostolskiej ludzi w podeszłym wieku

W świetle Pisma Świętego starość jawi się jako okres kumulowania mądrości i doświadczenia życiowego. Wydaje się, że obok zobowiązania chrzcielnego oraz przynależności do Kościoła, który z natury jest misyjny (zob. DM 2; DA 2), ten właśnie potencjał mądrości stanowi dodatkową podstawę do zaangażowania apostolskiego ludzi w podeszłym wieku. Jeżeli katolik świecki staje się uczestnikiem posłannictwa Kościoła także na mocy charyzmatów ${ }^{19}$, jakie otrzymał od Ducha Świętego (KK 33), to częstym charyzmatem ludzi w podeszłym wieku jest dar mądrości, poznania, wiary (zob. 1 Kor 12, 7-10; Rz 12, 6-8; 1 P 4, 10 11), a także największy zdaniem św. Pawła spośród wszystkich darów Ducha Świętego charyzmat miłości (1 Kor 13, 1-13). Z przyjęcia charyzmatów przez chrześcijanina wynika „prawo i obowiązek używania ich w Kościele i świecie dla dobra ludzi i budowania Kościoła” (DA 3). Ponieważ charyzmaty przyczyniają się do budowania królestwa Bożego na ziemi oraz wnoszą wkład w powiększanie dobra wspólnego i zaspokajanie potrzeb ludzi, powinny być przyjmowane

19 Zob. A. Czaja, Charyzmat, [w:] Leksykon teologii pastoralnej, dz. cyt., s. 138-142. 
z wdzięcznością zarówno przez otrzymujących, jak i przez pozostałych członków Kościoła (ChL 24).

W kontekście chrześcijańskiej wiary i nadziei starość może być przeżywana jako dar Boży i jako zadanie do wykonania. Św. Jan Paweł II mówił o „specjalnym charyzmacie, który zostaje udzielony starszemu, by we właściwy sposób wykorzystywał swoje talenty i siły fizyczne dla własnej satysfakcji i dla dobra innych" ${ }^{20}$. Charyzmaty typowe dla okresu starości, takie jak mądrość, doświadczenie życiowe, cierpliwe znoszenie cierpień i upokorzeń, umiłowanie modlitwy, stanowią mocną podstawę teologiczną do apostolskiego zaangażowania ludzi w podeszłym wieku.

Kościół z miłością postrzega ludzi starszych, starając się przyczyniać do powstania takiego środowiska społecznego i duchowego, w którym każdy człowiek mógłby przeżywać $\mathrm{w}$ pełni i z godnością ten ważny etap swojego życia. Według św. Jana Pawła II „podeszły wiek jest czasem łaski, który wzywa, aby z żarliwością i miłością zjednoczyć się ze zbawczą tajemnicą Chrystusa i głębiej uczestniczyć w realizacji Jego zamysłu zbawienia”21. Wiek emerytalny „otwiera przed ludźmi starszymi nowe możliwości kontynuowania przez nich

\footnotetext{
$20 \quad$ Jan Paweł II, Cenna rola osób starszych w Kościele, s. 39.

21 Jan Paweł II, Dar dtugiego życia. Homilia w czasie Wielkiego Jubileuszu ludzi starszych, 17 września 2000, „L'Osservatore Romano" wyd. pol. 21 (2000) 11-12, s. 14.
} 
pracy apostolskiej, którą winni oni odważnie podejmować, pokonując pokusy nostalgicznego zamykania się we wspomnieniach z przeszłości” (ChL 48). Ponieważ najbardziej naturalnym dla człowieka starego środowiskiem jest rodzina, staje się ona zarazem pierwszym i najważniejszym środowiskiem działalności apostolskiej seniorów. Do głównych zakresów posłannictwa ludzi w podeszłym wieku należy apostolat w dziedzinie kultury i edukacji, apostolat społeczno-charytatywny, apostolat cierpienia i apostolat modlitwy ${ }^{22}$.

3.1.

Apostolat w dziedzinie kultury i edukacji

Według nauczania Kościoła obecność ludzi w podeszłym wieku w kręgu rodzinnym ukazuje ciągłość pokoleń oraz wzajemne wspomaganie się w wypełnianiu różnych zadań i zdobywaniu świętości (KK 11). Zdaniem św. Jana Pawła II osoby starsze nie tylko gwarantują ciągłość pokoleń i pokazują wzajemną zależność ludu Bożego, ale także mają charyzmat przekraczania barier pomiędzy pokoleniami ${ }^{23}$. Lu-

22 Zob. W. Przygoda, Rodzina miejscem apostolatu ludzi w podeszłym wieku, [w:] Rodzina wobec współczesnych wyzwań społeczno-kulturowych, red. J. Gorbaniuk, B. Parysiewicz, Lublin 2009, s. 203-212.

23 „Ileż dzieci znalazło zrozumienie i miłość w oczach, słowach i pieszczotach osób starszych! Ileż osób starszych chętnie pod- 
dzie starzy są „strażnikami pamięci zbiorowej, a więc mają szczególny tytuł, aby być wyrazicielami wspólnych ideałów i wartości, które są podstawą i regułą życia społecznego" (LdS 10). Dlatego ludzie starzy mogą swoją wiedzą, dojrzałością i doświadczeniem służyć młodemu pokoleniu radami w dziedzinie życia społecznego, gospodarczego, politycznego i kulturalnego. „Społeczeństwo, które wyrzekłoby się ludzi starych, zaparłoby się nie tylko własnego pochodzenia, ale okradałoby samo siebie z własnej przyszłości”24. Kościół oczekuje od seniorów, aby stali się podmiotami ewangelizacji kultury, katechetami i świadkami życia w pełni chrześcijańskiego ${ }^{25}$.

Dokument II Polskiego Synodu Plenarnego podkreśla, że dziadkowie mogą przyczynić się do budowania więzi rodzinnych przez przykład właściwej hierarchii wartości, troski o przekaz wiary, pokój

pisuje się pod natchnionymi słowami biblijnymi, że «korona starców - synowie synów» (Prz 17, 6)". Jan Paweł II, Przemówienie do uczestników International Forum on Active Aging, 5 września 1980, „Insegnamenti di Giovanni Paolo II” (1980) 3/2, s. 539.

24 Jan Paweł II, Świat bez chorych byłby uboższy. Spotkanie z osobami starszymi, chorymi i ułomnymi w Haus der Barmherzigkeit w Wiedniu, 11 września 1983, [w:] Jan Paweł II, Ewangelia cierpienia. Wybór homilii, przemówień $i$ dokumentów, Kraków 1997, s. 77.

25 Pontificium Consilium pro Laicis, La dignità dellanziano, rozdz. V. 
wewnętrzny i zgodę w rodzinie ${ }^{26}$. Wzajemna miłość i komunia osób w rodzinie wielopokoleniowej jest dla wszystkich szkołą bogatszego człowieczeństwa. Młodzi małżonkowie, przeżywając swoje pierwsze trudności życiowe, mogą znaleźć w ludziach starszych osoby godne zaufania, przed którymi mogą się otworzyć i zasięgnąć u nich rady. Zadaniem dziadków w rodzinie wielopokoleniowej jest ewangelizacja młodszego pokolenia. Skuteczność ewangelizacji nie zawsze jest uzależniona od sprawnego działania, lecz od cierpliwości i poświęconego czasu, dlatego ludzie w podeszłym wieku mogą okazać się dobrymi ewangelizatorami. W wielu rodzinach dzieci i wnuki poznają podstawy wiary dzięki dziadkom, którzy mogą poświęcić im swój czas, podczas gdy rodzice zajęci są innymi sprawami ${ }^{27}$.

W Piśmie Świętym najważniejszym elementem i podstawą do szanowania osób starszych jest ich związek z mądrością życia (Hi 12, 12). Źródłem tego związku jest życiowe doświadczenie tych osób i ich wzrastająca łączność z Bogiem (Syr 25, 4-6). Mądrość, o której mówi Pismo Święte, nie jest tylko czysto ludzką refleksją nad światem i człowiekiem

26 II Polski Synod Plenarny (1991-1999), Powołanie do życia w malżeństwie i rodzinie, 13.

27 Papieska Komisja ds. Środków Społecznego Przekazu, Środki społecznego przekazu a problemy ludzi starych, 10 maja 1982. 
albo rezultatem tylko ludzkiego wysiłku umysłowego, jakim była grecko-rzymska filozofia ${ }^{28}$. Mądrość ta jest bezpośrednio związana $\mathrm{z}$ doświadczeniem religijnym i wiarą w Boga. Według tej koncepcji pełnię mądrości posiada tylko Bóg, a człowiek uzyskuje w niej udział przez swój związek z Bogiem i pełnienie Jego woli. Potwierdza to biblijne wyrażenie: „bojaźń Boża jest początkiem mądrości” (Prz 1, 7; Ps 111,10$)$. Św. Jan Paweł II zachęcał ludzi w podeszłym wieku, by tą mądrością wspomagali w trudzie wzrastania ludzi młodych oraz „poświęcali im czas i uwagę w momencie, gdy otwierają się na przyszłość i szukają swojego miejsca w życiu"29.

\section{2 .}

Apostolat społeczno-charytatywny

Według nauczania Kościoła istotą życia chrześcijańskiego jest miłość. Bóg, który jest wspólnotą miłości i życia, zaprosił w swoim Synu ludzi do budowania „wspólnoty życia i miłości” (KDK 48). Budowanie tej wspólnoty rozpoczyna się $\mathrm{w}$ rodzinie, ponieważ jest ona kolebką życia i miłości, a zarazem podstawową komórką społeczeństwa (ChL 40). Dlatego rodzina chrześcijańska powinna być miejscem humanizacji

\footnotetext{
28 E. Weron, O godna starość..., dz. cyt., s. 40-41.

29 Jan Paweł II, Dar dtugiego życia, dz. cyt., s. 14.
} 
osoby i społeczeństwa (ChL 40), a także szkołą życia społecznego (FC 43). Wypełnienie tej misji dokonuje się przez „miłość wobec dzieci, wobec chorych i starszych; poprzez wzajemną codzienną służbę wszystkich; poprzez dzielenie się dobrami, radościami i cierpieniami" (FC 21).

W rodzinie chrześcijańskiej „różne pokolenia spotykają się i pomagają sobie wzajemnie w osiąganiu pełniejszej mądrości życiowej oraz $\mathrm{w}$ godzeniu praw poszczególnych osób z wymaganiami życia społecznego" (KDK 52). Ukształtowana w duchu chrześcijańskim rodzina nie zamyka się w sobie, ale otwiera się na inne rodziny i na społeczeństwo (FC 42). Dlatego od miłości i troski o pogłębianie więzi rodzinnych zależy również powodzenie misji budowania więzi w szerszej społeczności. Nie da się zbudować postulowanej przez bł. Pawła VI i św. Jana Pawła II cywilizacji miłości ani w narodzie, ani w społeczności międzynarodowej bez umacniania miłości $\mathrm{w}$ rodzinie, gdyż rodzina jest sercem cywilizacji miłości ${ }^{30}$.

Katolicy świeccy są wezwani szczególnie do tego, aby miłością i służbą przywracać stworzeniu jego pierwotną wartość, a ludzką kulturę przepajać wartościami chrześcijańskimi (ChL 14). Świadectwo Chrystusa zobowiązuje również katolików w podeszłym

30 Jan Paweł II, Gratissimam sane. List do rodzin z okazji Roku Rodziny, 2 lutego 1994, 13. 
wieku do zaangażowania się w budowanie cywilizacji miłości. Na miarę swoich możliwości fizycznych, psychicznych i duchowych ludzie starsi są zaproszeni do poświęcenia przynajmniej części swego wolnego czasu na zaangażowanie się $\mathrm{w}$ różne formy wolontariatu $^{31}$, którego pierwszą szkołą jest życie rodzin$\mathrm{ne}^{32}$. W Polsce przeważającą większość wolontariuszy w parafialnych zespołach Caritas stanowią ludzie w podeszłym wieku. Szkoda tylko, że niespełna połowa polskich parafii takowe zespoły posiada. Również ze względu na duże możliwości aktywizacji ludzi starszych warto powołać parafialne zespoły Caritas we wszystkich parafiach.

W Polsce ludzie starsi są aktywnymi propagatorami kultu miłosierdzia Bożego i faktycznie go rozwijają w formach przekazanych przez św. Faustynę Kowalską. Warto przy tej okazji proponować im zaangażowanie $\mathrm{w}$ apostolat miłosierdzia, gdyż z wytrwałej modlitwy powinny rodzić się czyny miłosierdzia chrześcijańskiego. Apostolat miłosierdzia polega na naśladowaniu Chrystusa w dziele pojednania ludzi skłóconych z samym sobą, z bliźnimi i z Bogiem oraz na naśladowaniu Go w uczynkach miłosierdzia. Jak

31 Pontificium Consilium pro Laicis, La dignità dell'anziano, rozdz. V.

32 Zob. M. Kalinowski, Wolontariat w życiu rodziny, „Roczniki Teologiczne" 51 (2004) z. 10, s. 151-163. 
przed 2 tysiącami lat, tak również współcześnie Chrystus pragnie jednać ludzi z Bogiem i ze sobą nawzajem, uzdrawiać chorych, stawiać na nogi tych, którzy się źle mają, dzielić chleb wśród głodnych, wskazywać drogę zagubionej młodzieży, błogosławić dzieci, ale dzisiaj potrzebuje do tego umysłów i serc, rąk i nóg, a nade wszystko zapału i miłości swoich uczniów ${ }^{33}$. Temu oczekiwaniu mogą wyjść naprzeciw wolontariusze w podeszłym wieku.

Podczas podróży apostolskiej do Polski w 2002 roku św. Jan Paweł II przypomniał, że współczesny człowiek, tak bardzo dotknięty tajemnicą nieprawości, potrzebuje orędzia o Bogu, który jest miłosierny i kocha człowieka nawet wtedy, gdy ten zgrzeszy. Podczas Eucharystii na Krakowskich Błoniach papież apelował, aby Polacy stali się świadkami miłosierdzia. „Nadszedł czas - podkreślał - aby orędzie o Bożym miłosierdziu wlało w ludzkie serca nadzieję i stało się zarzewiem nowej cywilizacji - cywilizacji miłości. To orędzie Kościół pragnie niestrudzenie głosić nie tylko żarliwym słowem, ale także gorliwą praktyką miłosierdzia"34. Wydaje się, że ten apel $\mathrm{w}$ pierwszej kolejności powinni odnieść do

33 W. Przygoda, Apostolat miłosierdzia w świetle nauczania Jana Pawła II, „Roczniki Teologiczne” 53 (2006) z. 6, s. 55.

34 Jan Paweł II, Homilia podczas Mszy św. beatyfikacyjnej, Kraków, 18 sierpnia 2002, „L'Osservatore Romano” wyd. pol., 23 (2002) 9, s. 20. 
siebie wolontariusze chrześcijańscy, w tym także wolontariusze w podeszłym wieku, gdyż nie da się żyć miłosierdziem Bożym i głosić go - bez potwierdzenia go czynami miłości.

\section{3.}

Apostolat cierpienia

Apostolat cierpienia pełnią osoby najsłabsze fizycznie, głównie należące do tzw. czwartego wieku, a polega on na dopełnianiu braków udręk Chrystusa dla dobra członków wspólnoty kościelnej. Ta forma apostolatu znajduje swoje podstawy w odkupieńczych źródłach krwawej ofiary złożonej przez Jezusa Chrystusa na Golgocie w Wielki Piątek. Kościół wyrósł z Chrystusowego krzyża i tylko dzięki jego mocy utrzymuje swoją duchową płodność, dlatego nie może się wyrzec cierpienia pod groźbą utraty swojej tożsamości, chociaż cieszy się już radością nowego życia, którym pragnie dzielić się ze wszystkimi ludźmi ${ }^{35}$. Jezus Chrystus powołuje uczniów do wzięcia swojego krzyża, ponieważ On sam cierpiał za wszystkich i wszystkim zostawił wzór (zob. 1 P 2, 21). Chrystus włącza do swojej ofiary odkupieńczej tych, którzy z niej korzystają, dlatego chrześcijanin żywiący się Eucharystią

35 M. K. Sulej, Od teologii cierpienia do teologii krzyża, „Ateneum Kapłańskie” 109 (1987) nr 470, s. 15. 
nie może równocześnie wyrzec się Chrystusowego krzyża.

Z obrazu Kościoła jako Mistycznego Ciała Chrystusa rodzi się świadomość duchowej jedności wszystkich wierzących z Chrystusem i między sobą. Prawda ta ma swoje odniesienie do poszukiwań sensu ludzkiego cierpienia ${ }^{36}$, a najgłębiej wyraził ją Apostoł Narodów w następujących słowach: „Teraz raduję się w cierpieniach za was i ze swej strony w moim ciele dopełniam braki udręk Chrystusa dla dobra Jego Ciała, którym jest Kościół" (Kol 1, 24). W tajemnicy paschalnej Chrystus dał początek zjednoczenia z człowiekiem we wspólnocie Kościoła. W sposób szczególny Chrystus jednoczy się z każdym człowiekiem cierpiącym, który przez wiarę odnajduje w Jego cierpieniach nowy sens i znaczenie swoich cierpień ${ }^{37}$.

W swoich cierpiących członkach Kościół dostrzega źródło swojej nadprzyrodzonej siły. Przedziwnym paradoksem wiary jest fakt, że „źródła mocy Bożej biją właśnie z pośrodka ludzkiej słabości. Uczestnicy cierpień Chrystusa przechowują w swoich własnych cierpieniach najszczególniejszą cząstkę nieskończonego

36 Zob. U. Dudziak, W. Przygoda, W poszukiwaniu sensu cierpienia. Aspekt psychologiczny i teologiczny, „Roczniki Teologiczne" 53 (2006) z. 10, s. 79-93.

37 Jan Paweł II, Salvifici doloris. List o chrześcijańskim sensie ludzkiego cierpienia, 11 lutego 1984, 20. 
skarbu Odkupienia świata"38. Pośród ludzkich cierpień działa sam Odkupiciel, który poprzez Ducha Świętego tak oddziałuje na człowieka cierpiącego, że przemienia go od wewnątrz, wskazując mu miejsce blisko siebie. W ten sposób Chrystus przetwarza substancję życia duchowego cierpiącego, kierując go ku wyżynom dojrzałości chrześcijańskiej. Ze współdziałania cierpiącego z łaską Boskiego Odkupiciela rodzą się wielkie owoce duchowe, które stanowią „przejmującą lekcję dla ludzi zdrowych i normalnych"39. Apostolstwo cierpienia polega na tym, aby przeżywać je w ścisłym zjednoczeniu z Chrystusem w celu budowania Kościoła i zbawienia całego świata. Tak przeżywane cierpienie staje się narzędziem wyzwalania miłości i przetwarzania ludzkiej cywilizacji w „cywilizację miłości”" Ważnym zadaniem duszpasterskim jest pomoc ludziom starszym w tym, by swemu cierpieniu nadali charakter apostolski i misyjny ${ }^{41}$.

\footnotetext{
38 Jan Paweł II, Salvifici doloris, 27.

39 Jan Paweł II, Salvifici doloris, 26.

40 Jan Paweł II, Salvifici doloris, 30.

41 „Św. Teresa od Dzieciątka Jezus - patronka misji, niewolnica miłości w Karmelu w Lisieux - pragnęła przemierzyć świat cały, aby wznieść Krzyż wszędzie, na każdym miejscu. [...] Zrealizowała konkretnie powszechność i ducha apostolskiego swych pragnień w wyproszonym u Boga cierpieniu i w cennym darze dobrowolnej ofiary, złożonej z samej siebie w imię miłosiernej miłości. Jej cierpienie osiągnęło szczyt, a jednocześnie najwyższy stopień apostolskiej
} 
Istotę apostolatu cierpienia dobrze oddają słowa, które św. Jan Paweł II wygłosił na spotkaniu z ludźmi chorymi i cierpiącymi podczas pobytu w Krakowie 9 czerwca 1979 roku:

Wy słabi, fizycznie słabi, poddani cierpieniu, jesteście równocześnie - a $\mathrm{w}$ każdym razie możecie być - źródłem mocy dla innych, dla zdrowych. Czasem dla tych, którzy swoje zdrowie źle wykorzystują, którzy obrażają Boga swoim zdrowiem i swoimi siłami. Wy, chorzy i cierpiący, jesteście dla nich nie tylko wyrzutem, ale także i nawróceniem. Nawrócenie grzeszników idzie poprzez wasze cierpienie, jestem o tym najgłębiej przekonany. [...] Czyńcie zbawienny pożytek z krzyża, który stał się udziałem każdego $\mathrm{z}$ was. Proszę dla was o łaskę światła i mocy duchowej w cierpieniu, abyście nie upadli w sercu, ale sami widzieli sens i drugich swą modlitwą i ofiarą dźwigali ${ }^{42}$.

płodności w męczeństwie ducha, w udręce ciemności wiary, które ofiarowała heroicznie, aby pozyskać światło wiary dla tak wielu braci pogrążonych w ciemnościach". Jan Paweł II, Misyjna moc cierpienia. Orędzie na Światowy Dzień Misyjny, 10 czerwca 1984, 2.

42 Jan Paweł II, Do chorych, [w:] Jan Paweł II w Polsce 2-10 czerwca 1979. Przemówienia. Reportaże. Sprawozdania, red. M. Maciołka, Poznań 1982, s. 238-239. 


\section{4.}

Apostolat modlitwy

Według nauczania św. Jana Pawła II przywilejem ludzi starszych jest czas, którego nie rozpraszają już rozliczne zajęcia i który może „sprzyjać głębszej refleksji i dłuższemu dialogowi z Bogiem"43. Jeżeli dar modlitwy jest dzielony z innymi, chociażby przez więź duchową, to taka modlitwa staje się apostolatem. Tym bardziej apostolskiego charakteru nabiera zaangażowanie w utrzymanie miejsc kultu oraz podejmowanie posług liturgicznych, zwłaszcza stałych diakonów, szafarzy nadzwyczajnych Komunii św., akolitów, lektorów, komentatorów, animatorów nabożeństw, krzewicieli kultu maryjnego i świętych ${ }^{44}$. Kościół wciąż potrzebuje i liczy na wytrwałą modlitwę ludzi w podeszłym wieku, zarówno seniorów świeckich, starych zakonników i zakonnic, jak i emerytowanych biskupów i prezbiterów (LdS 13).

Doświadczenie Kościoła wskazuje, że okres starości sprzyja odnowie duchowej i zbliżeniu do Boga poprzez refleksję nad słowem Bożym i życie sakramentalne. Jest to okres odzyskanej wolności od naporu ślepej namiętności i trudnych do opanowania we

\footnotetext{
43 Jan Paweł II, Dar długiego życia, s. 14.

44 Pontificium Consilium pro Laicis, La dignità dell'anziano, rozdz. V.
} 
wcześniejszych okresach życia instynktów: seksualnego oraz posiadania i gromadzenia dóbr ${ }^{45}$. Starość jest więc czasem stosownym do robienia remanentu duchowego po okresach młodzieńczym i dojrzałym, a także czasem naprawiania błędów i wyrównywania krzywd. Trzeci wiek jest również czasem odkrywania prawdy o szczęściu bezinteresownego dawania siebie innym (zob. Dz 20, 35). Dziadkowie obdarowując innych, zwłaszcza wnuków, dojrzewają do pełni człowieczeństwa i zbliżają się do doskonałości życia chrześcijańskiego. Zdobyte przez lata doświadczenia pomagają osobom starszym dostrzegać ograniczenie spraw tego świata i głębiej odczuwać potrzebę obecności Boga w życiu doczesnym. Natomiast rozczarowania doznane w różnych okolicznościach uczą pokładać nadzieję w Bogu. Ta mądrość ludzi w podeszłym wieku, zdobywana przez wiele lat, może służyć jako świadectwo nie tylko najbliższym krewnym, lecz także szerszej wspólnocie chrześcijańskiej ${ }^{46}$.

Starość w świetle Bożych zamysłów jest uwieńczeniem całego procesu duchowego wzrastania, mającego na celu osiągnięcie chrześcijańskiej doskonałości i świętości życia. Jest to zatem czas stosowny do rozwijania intensywniejszej modlitwy indywidualnej

\footnotetext{
45 E. Weron, O godna starość..., dz. cyt., s. 32-33.

46 Jan Paweł II, Cenna rola osób starszych w Kościele, dz. cyt., s. 39 .
} 
i wspólnotowej, np. w grupach religijnych, zespołach apostolskich lub ruchach odnowy charyzmatycznej, a także do częstej i pogłębionej lektury Pisma Świętego. Wielu ludzi starszych praktykuje regularną spowiedź, głównie w pierwsze piątki miesiąca, a także codziennie lub prawie codziennie uczestniczy we Mszy św., co jest godne uznania i polecenia innym. Papież Franciszek zauważył, że zarówno starzec Symeon, jak i prorokini Anna byli ludźmi wrażliwymi na działanie Ducha Świętego i dużo czasu spędzali w świątyni ${ }^{47}$. To dobry przykład dla współczesnych seniorów i zachęta do kształtowania przez nich podobnej postawy.

W okresie starości wielu ludzi w podeszłym wie$\mathrm{ku}$ pielęgnuje dziecięctwo duchowe. Jest ono przywilejem, a zarazem zadaniem okresu starości polegającym na dążeniu do ewangelicznej doskonałości (zob. Mt 18, 3). Szczególna więź łączy osoby w podeszłym wieku z dziećmi. Często dzieci lepiej rozumieją się ze swymi dziadkami niż z rodzicami. Przyczyną tego zjawiska może być wypracowanie przez ludzi starszych dziecięcej prostoty, ufności względem Boga jako Ojca, dobroci wobec ludzi i czystości serca. Starość jest ostatnim sygnałem do przyswojenia sobie takich postaw wobec Boga i ludzi. Lekturą godną

47 Zob. Franciszek, Spotkanie Jezusa z Jego ludem. Homilia podczas Mszy św. w święto Ofiarowania Pańskiego, 2 lutego 2014, „L'Osservatore Romano” wyd. pol. 35 (2014) 2, s. 26-27. 
polecenia seniorom jest dzieło św. Teresy od Dzieciątka Jezus pt. Dzieje duszy, które jest najlepszym podręcznikiem drogi duchowego dziecięctwa. Istotą tej drogi jest wypracowanie $\mathrm{w}$ sobie postawy dziecięcej prostoty, pokory i ufności, której źródłem są trzy wielkie chrześcijańskie cnoty: wiara, nadzieja i miłość ${ }^{48}$. Aktualność drogi dziecięctwa duchowego potwierdził św. Jan Paweł II w Liście do dzieci: „Niebo jest dla tych, którzy są prości jak dzieci, tak pełni zawierzenia jak one, tak pełni dobroci i czystości. Tylko tacy mogą odnaleźć w Bogu swego Ojca i stać się za sprawą Jezusa również dziećmi Bożymi”"49.

W Polsce świeccy katolicy trzeciego wieku są niezastąpionymi apostołami, szczególnie $\mathrm{w}$ dziedzinie budowania więzi rodzinnych, działalności charytatywnej, zbawczym przeżywaniu cierpienia i modlitwie. Wyzwaniem duszpasterskim jest troska o to, by seniorzy byli świadomi swoich zadań apostolskich w przeżywanej przez nich fazie życia. Należy im przypominać, że czas ten nie może być dla nich samych czasem straconym, gdyż jego nadmiar stwa-

\footnotetext{
48 E. Weron, O godnq starość..., dz. cyt., s. 35.

49 Jan Paweł II, Tra pochi giorni. List do dzieci w Roku Rodziny, 13 grudnia 1994, 1.
} 
rza wreszcie możliwość spokojnej refleksji nad najważniejszymi kwestiami życia, które wcześniej były pomijane z uwagi na sprawy bardziej naglące. Jak zauważył św. Jan Paweł II, świadomość bliskości ostatecznego kresu „skłania człowieka starszego do skoncentrowania się na tym, co istotne, i docenienia tego, co niszczeje z upływem lat" ${ }^{50}$.

Duszpasterstwo i zaangażowanie apostolskie seniorów domagają się obecnie uznania i wyraźniejszego dowartościowania w życiu Kościoła. Papież Franciszek w adhortacji apostolskiej Evangelii gaudium przypomniał nam wszystkim, iż jako chrześcijanie ,jesteśmy powołani do troski o najbardziej kruchych mieszkańców ziemi” (nr 209). Do nich obok dzieci niewątpliwie należą ludzie $\mathrm{w}$ podeszłym wieku. I chociaż na pozór nie przynosi nam to namacalnych i natychmiastowych korzyści - uczy papież Franciszek - to ,jest rzeczą nieodzowną, by być blisko nowych form ubóstwa i kruchości, w których jesteśmy wezwani do rozpoznania Chrystusa cierpiącego" (tamże, nr 210). Ostatecznie seniorzy stanowią szansę dla pozostałych grup wiernych na rozpoznanie w nich ukrytego Chrystusa i okazanie Mu miłosierdzia (por. Łk 10, 37).

50 Jan Paweł II, Bo tu jest twoje życie i dtugie trwanie twego pobytu na ziemi, 3. 


\section{Summary}

The specificity of the senior age is becoming better recognized by gerontology, psychology, sociology and related sciences. It is also a serious challenge for the Church, because this community wants to provide pastoral care for all his faithful adequate to their needs. In this study were firstly presented specific religious needs of the elderly. The objectives and forms of pastoral seniors have also been described. In the final part of this article an apostolic activation of older people was underlined. From the point of view of the people involved it is paramount. The lay Catholics in Poland who are in old age are irreplaceable apostles, especially in the field of building of family bonds, charity, experience of suffering and prayer. The task of the clergy is apostolic formation of seniors, as well as animation of apostolic groups of old people in parishes. 


\section{Bibliografia}

Jan Paweł II, „Salvifici doloris”. List o chrześcijańskim sensie ludzkiego cierpienia, 11 lutego1984.

Jan Paweł II, Cenna rola osób starszych w Kościele. Audiencja generalna, 7 września1994 .

Jan Paweł II, List do osób w podeszłym wieku, 1 października 1999.

Jan Paweł II, Dar długiego życia. Homilia w czasie Wielkiego Jubileuszu ludzi starszych, 17 września 2000.

Jan Paweł II, Bo tu jest twoje życie i długie trwanie twego pobytu na ziemi. Orędzie na Wielki Post 2005, 8 września 2004.

Franciszek, Spotkanie Jezusa z Jego ludem. Homilia podczas Mszy św. w święto Ofiarowania Pańskiego, 2 lutego 2014.

Papieska Komisja ds. Środków Społecznego Przekazu, Środki społecznego przekazu a problemy ludzi starych, 10 maja 1982.

Pontificium Consilium pro Laicis, La dignità dell'anziano e la sua missione nella Chiesa e nel mondo, 1 października 1998.

Baumgartner K., Alte Menschen, [w:] Handbuch praktische Theologie, Mainz 2000, t. 2, s. 61-71.

Dudziak U., Przygoda W., W poszukiwaniu sensu cierpienia. Aspekt psychologiczny i teologiczny, „Roczniki Teologiczne” 53 (2006) z. 10, s. 79-93.

Dziedzic J., Das Alter - ein Problem oder eine Chance? Versuch einer multiperspektivischen pastoralen Refleksion, „Analecta Cracoviensia" 43 (2011), s. 25-41.

Kluz M., Starość i jej problemy we współczesnej cywilizacji, [w:] Przestrzenie pracy socjalnej, red. J. Stala, Tarnów 2010, s. 89-106. 
Krzyżagórska B., Ludzie starsi - nadzieją Kościoła i społeczeństwa, www.orrk.pl/index.php/kongresy-tematyczne/apostolstwo-ludzi-starszych (7.05.2014).

Ostrowski J., Przygoda W., Seniorów duszpasterstwo, [w:] Leksykon teologii pastoralnej, red. R. Kamiński, W. Przygoda, M. Fiałkowski, Lublin 2006, s. 789-783.

Przygoda W., Rodzina miejscem apostolatu ludzi w podeszłym wieku, [w:] Rodzina wobec współczesnych wyzwań społeczno-kulturowych, red. J. Gorbaniuk, B. Parysiewicz, Lublin 2009, s. 203-212.

Przygoda W., Starych duszpasterstwo, [w:] Encyklopedia katolicka, red. E. Gigilewicz i in., t. 18, Lublin 2013, kol. 868-870.

Weron E., O godna starość. Refleksje człowieka wierzacego, Poznań 2000.

Żaba M., Ludzie starsi w Kościele, „Caritas” (2012) nr 4, s. 10-11. 